\title{
A Review of Eco-labels and their Economic Impact
}

\author{
Maïmouna YOKESSA \\ UMR Économie Publique, AgroParisTech, Université Paris-Saclay* \\ Stephan MARETTE \\ UMR Économie Publique, INRA, Université Paris-Saclay
}

\begin{abstract}
In many countries, various eco-labels have emerged for informing consumers about the environmental impact of the offered products. Using recent advances in the empirical and theoretical literature, this review questions the efficiency of eco-labeling. We combine a literature review with discussions of empirical examples. We underline the limitations of eco-labels for signaling credible information to consumers. In particular, both the complexity and the proliferation of eco-labels are likely to hamper their efficiency in guiding consumers. From a regulatory perspective, several studies show that eco-labels are useful, but they cannot be considered a panacea for improving environmental quality. Indeed, it is often socially optimal to combine eco-labels with other regulatory tools such as standards banning polluting products and tax/subsidy mechanisms depending on the environmental quality. The conclusion suggests research priorities for tackling unanswered questions.
\end{abstract}

\section{Introduction}

An eco-label can be defined as a simple signal that can be posted by several competitors to induce consumers to purchase eco-friendly products (Teisl et al., 1999). In many countries, there is demand for goods and services with high environmental quality, as some consumers have a growing awareness of the impact of their consumption on the environment (Tranter et al., 2009). Consumers' perceptions of environmental damage are often linked to perceptions of their health. Demand for eco-friendly and sustainable goods, thus, creates an opportunity for firms to offer eco-friendly products. Firms use eco-labels to notify consumers about the

*Maïmouna YOKESSA, 16 rue Claude Bernard 75005 PARIS (FRANCE), maimouna.yokessa@inra.fr 
higher quality of their goods (Teisl \& Roe, 1998). The growing market for green products is leading to an increase in the number and diversity of eco-labels. In fact, environmental labeling increased six fold between 1990 and 2010 (Gruère, 2014). According to the website of Ecolabel Index (2018), there were 463 eco-labels in 199 countries and 25 industry sectors in 2018. This proliferation of eco-labels in some situations limits the favorable effects that environmental information has on consumer behavior, instead producing undesirable effects (Grunert, 2011).

In many situations, consumers are imperfectly informed about the environmental impact of their purchases and cannot internalize hard-to-estimate environmental externalities. They make choices ignorantly or based on uncontrolled messages and rumors. Environmental attributes cannot be checked before the purchase, nor can they be determined through the experience of the consumption of a good (Ford et al., 1988), which corresponds to credence characteristics (Darby \& Karni, 1973). A situation without credible signals entails a market failure, leading to the absence of high-quality products (Akerlof, 1970). Eco-labels, by informing consumers, help them internalize environmental characteristics and purchase high-quality products. Consumers, firms, governments, and non-governmental organizations (NGOs) have different motivations and interests regarding the existence of eco-labels.

Eco-labels can be part of an environmental policy. In this respect, creating public ecolabels or imposing mandatory ones are policy options that can accompany or replace taxation and norms (Golan et al., 2001). In other cases, the use of eco-labels as a policy instrument provides incentives to producers to attract consumers with a high willingness to pay (WTP) (Crespi \& Marette, 2005). However, accounting for incentives and markets adjustments is particularly challenging for the decision maker. Information about products' characteristics should be taken into account, and a cost/benefit analysis is necessary to assess the relevance of a public intervention on the market (Crespi et al., 2003).

This study aims to (1) describe incentives for the use of eco-labels, (2) assess the limitations of eco-labels, and (3) discuss the relevant use of eco-labels as a policy instrument. It uses the recent main advances from empirical contributions, such as experimental economics and hedonic prices, and theoretical contributions, such as industrial organization, environmental economics, and regulatory economics. As various contributions proliferate, we select those most significant for illustrating our purpose. The literature is divided into two main fields. The first field encompasses numerous empirical studies eliciting premiums for various ecofriendly characteristics. Indeed, numerous articles examine both consumers' WTP and the factors altering such willingness. The second field comprises theoretical studies describing the mechanisms used to improve the functioning of eco-labels.

This review adds to the literature by focusing on some of the overlooked questions related to the regulation. The previous works by Galarraga Gallastegui (2002), Gruère (2014), Horne (2009), Prieto-Sandoval et al. (2016), and Walter \& Chang (2017) have mainly described the motivations, market incentives, and limitations of eco-labels. Although we tackle these issues, 
we also underline the various options for public regulation on eco-labeling. ${ }^{1}$

The remainder of this paper is organized as follows. The next section presents some of the characteristics of eco-labels. The market incentives for adopting eco-labels are presented in section 3. The limitations of eco-labels are presented in section 4 . Section 5 assesses the relevance of the use of eco-labels as a policy instrument. The last section suggests research priorities for tackling the remaining unanswered questions.

\section{Characterization of eco-labels}

In this study, we restrict our attention to eco-labels that are either signals that distinguish products according to environmental criteria or declarations providing quantitative indicators of environmental performance (see the ISO 14020 definitions (ISO, 1999a,b)). It is relevant to characterize eco-labels using various criteria such as communication channel (e.g., business-to-business, business-to-consumer, business-to-government, government-toconsumer), category of goods and services targeted (e.g., agriculture and food, electronics, transportation, textile products, tourist services), environmental attribute (e.g., natural resources, sustainability, biodiversity, source of pollution), ownership (e.g., private, public, non-profit, hybrid), mode of governance (e.g., voluntary versus mandatory), and scope (e.g., regional, national, international).

In this study, we only focus on the business-to-consumer communication channel. Many of our examples come from agriculture and food because this sector accounts for the highest number of eco-labels (Gruère, 2014) such as organic labels, Marine Stewardship Council labels, and rainforest labels. Regarding services, eco-labeling has recently grown in the tourism sector, with the Green Globe label and Blue Flag label signaling pure water and a clean coast for 4,554 beaches in 45 countries in 2018 (see Blue Flag, 2018). In the energy sector, the famous Energy Star label is a U.S. Environmental Protection Agency label widely posted on many electric appliances to signal energy efficiency (see Energy star, 2018). For the energy sector, Hahn \& Metcalfe (2016) showed that information can help promote reductions in energy use.

The ownership of eco-labels is also important because this may sway the credibility of the label. Eco-labels are mainly owned by private entities or NGOs. In 2012, public-owned eco-labels only represented one-sixth of existing eco-labels (Gruère, 2014). Most eco-labels globally are voluntarily adopted by firms; however, some characteristics can be defined by the regulator, as is the case for organic labels. Mandatory labels appear as an exception in the eco-label setting.

\footnotetext{
${ }^{1}$ For a broad view of the economic effects, readers can consult the book edited by Teisl (2017) and special issue of the Journal of Agricultural and Food Industrial Organization published in 2009 entitled "Quality promotion through eco-labeling" (see Costa et al., 2009). A complete review of high-quality certification was provided by Dranove \& Jin (2010).
} 
For many products, those with eco-labels represent a small proportion of sold products, with market shares lower than $5 \%$ or even lower than $1 \%$. However, when consumers are aware of an environmental problem, an eco-label may provide a strong incentive. For example, the dolphin-safe label was widely adopted by fishers in the 1990s and led to an impressive reduction in the number of dolphins killed (see Teisl et al., 2002b; IATTC, 2018). The dolphin-safe labeling of canned tuna thus significantly altered consumer behaviors. Likewise, toilet paper and detergents with the eco-label Nordic Swan are also largely consumed in Nordic countries (Bjørner et al., 2004). Forest Stewardship Council and Pan European Forest Certification labels are also widely adopted for wood products and recycled paper (Teisl, 2003; Teisl et al., 2002a) showed that the environmental labeling of wood products influences consumers' purchase decisions, particularly for products such as recycled paper for which they perceive a clear connection between high usage and the environmental impact.

Beyond the previous examples, the general characterization of the market shares of products with eco-labels is hazardous as they depend on many idiosyncratic parameters such as consumers' awareness, generic advertising, supply chain organization, and the accuracy of the certification process. We now turn to consumers' motivation to purchase green products.

\section{Market incentives for adopting eco-labels}

This section presents the main works focusing on the market mechanisms and adoption of eco-labels by private agents. Akerlof (1970) showed that imperfect information on products' characteristics leads to market failures, with high-quality products being driven out of the market. Eco-labels are a response toward thwarting such market failure. Here, we describe consumers' preferences and firms' incentives for adopting eco-labels.

\subsection{Consumers' choices}

By choosing "clean and green" goods and services, consumers play a significant role in decreasing the environmental damage caused by production chains. Indeed, by changing demand for products' attributes, they choose which products produced and how. The efficiency of an eco-label depends on consumers' sensitivity toward the environment (e.g., their carbon footprint). If they have little interest in sustainability, the effect of eco-labels may be limited and perhaps insignificant. The price of products with eco-labels is the main factor limiting their purchases, especially for low-income consumers.

Most empirical research on eco-labels focuses on consumers' choices and preferences. Some studies directly measure the impact of eco-labels on market prices (Nimon \& Beghin, 1999a). For instance, using consumer panel data and estimating hedonic prices, Jaffry et al. (2004), Brécard et al. (2009), and Roheim et al. (2011) showed the existence of a significant price premium for fish with eco-labels. These studies describe the significant but low price 
premium between green and regular products.

Other studies elicit WTP using surveys and experiments on the logos and messages revealed to participants by products . The initial contributions by Blend \& van Ravenswaay (1999) and Loureiro et al. (2001) showed that some consumers pay a premium for environmentally friendly products (Tranter et al., 2009), which means that their WTP for a product with an eco-label is higher than that for an "equivalent" product without an eco-label. Although empirical economics have shown that consumers care about the environmental impact of the goods they buy, their WTP is often relatively low. As shown by the examples in Table 1, the WTP for food with eco-labels has been intensively estimated. In Table 1, we restrict our attention to a few representative studies. An exhaustive study of WTP could lead to a meta-analysis that aims to measure the factors swaying WTP and premiums.

In Table 1, the type of good is in the second column and the methodology used to elicit WTP is in the fourth column. Surveys and lab experiments are useful for eliciting wellinformed, thoughtful preferences. However, upward biases for WTP are likely because of the artificial environment and limited number of products examined, while real-life choices imply multiple and quick decision making under quality uncertainty, information overload, and / or imperfect recall. Using a meta-analysis, List \& Gallet (2001) found that on, average, participants overstate their preferences, including WTP and willingness-to-accept, in hypothetical settings. Nonetheless, even though WTP can be overstated when using a hypothetical methodology, a strictly positive WTP confirms a consumer's interest in an environmental characteristic. Despite possible biases, the studies in Table 1 thus indicate real intent to pay more for eco-labels when the WTP for eco-labeled products is higher than that for regular products.

The last column of Table 1 shows that the WTP for green food is significantly higher than the WTP for regular food in most cases. In other words, these positive WTP differences between green and regular products are robust irrespective of the type of eco-label, type of food, and country. In this table, there is only one non-food product (roses), and Michaud et al. (2013) found a premium for environmental attributes signaled by eco-labels and/or carbon footprints. Table 1 confirms that consumers' sensitivity explains the emergence of voluntary eco-labels in various markets. However, disentangling the motivations behind these consumption decisions is challenging. It is unknown whether eco-labeled products are chosen for (1) a pure altruistic reason for the environment, (2) a warm-glow effect satisfying a consumer's utility or ego (see Andreoni, 1990), (3) a selfish reason, when a green characteristic is positively correlated with other characteristics such as health benefits and taste (Bougherara \& Combris, 2009), or (4) a positional effect indicating the high income of the purchaser Grolleau et al. (2012).

An eco-label is selected for products characterized as "impure public goods," namely those generating numerous private attributes that directly affect consumer utility and certain public attributes that affect the environment and society as a whole (see Kotchen, 2005). Such 
Table 1: Examples of experiments on eco-labels published between 2007 and 2016

\begin{tabular}{|c|c|c|c|c|c|}
\hline References & Products & Countryies & Methods & Eco-labels & $\begin{array}{l}\text { Impact on } \\
\text { the market }\end{array}$ \\
\hline Marchi et al. (2016) & Yogurt & US & $\mathrm{HCE}$ & $\begin{array}{l}\text { USDA Organic } \\
\text { Carbon Trust }\end{array}$ & $\begin{array}{l}+ \\
+\end{array}$ \\
\hline Van Loo et al. (2015) & Coffee & US & $\mathrm{HCE}$ & $\begin{array}{l}\text { USDA Organic } \\
\text { Rainforest } \\
\text { Fair Trade } \\
\text { Carbon Footprint }\end{array}$ & $\begin{array}{c}+ \\
+ \\
+ \\
\text { N.S. }\end{array}$ \\
\hline Van Loo et al. (2014) & Chicken & Belgium & HCE & $\begin{array}{l}\text { EU Organic } \\
\text { Belgium Organic } \\
\text { EU AW } \\
\text { CF - } 20 \% \\
\text { CF - } 30 \% \\
\text { Free range claim }\end{array}$ & $\begin{array}{l}+ \\
+ \\
+ \\
+ \\
+ \\
+\end{array}$ \\
\hline Caputo et al. (2013a) & Tomatoes & US & $\mathrm{HCE}$ & $\begin{array}{l}\text { USDA Organic } \\
\mathrm{Nkm} \\
\mathrm{CO}_{2} \text { emission }\end{array}$ & $\begin{array}{l}+ \\
+ \\
+\end{array}$ \\
\hline Michaud et al. (2013) & Roses & France & RCE & $\begin{array}{l}\text { FFFP } \\
\text { Carbon Footprint }\end{array}$ & $\begin{array}{l}+ \\
+\end{array}$ \\
\hline Schmit et al. (2013) & Wine & US & HCE & $\begin{array}{l}\text { Shoot Thinning } \\
\text { Leaf Removal } \\
\text { STLR }\end{array}$ & $\begin{array}{l}+ \\
+ \\
+\end{array}$ \\
\hline Sörqvist et al. (2013) & Coffee & Sweden & SPLE & e-f & + \\
\hline Disdier \& Marette (2012) & Shrimp & France & SPLE & $\mathrm{EF}$ & + \\
\hline Xu et al. (2012) & Seafood & China & $\mathrm{CV}$ & $\begin{array}{l}\text { Eco-label } \\
\text { Green Label }\end{array}$ & $\begin{array}{l}+ \\
+\end{array}$ \\
\hline Aprile et al. (2012) & Olive Oil & Italy & $\mathrm{HCE}$ & $\begin{array}{l}\text { PDO } \\
\text { PGI } \\
\text { Organic Farming }\end{array}$ & $\begin{array}{l}+ \\
+ \\
+\end{array}$ \\
\hline Olesen et al. (2010) & Salmon & Norway & RCE & $\begin{array}{l}\text { Freedom Food } \\
\text { Organic }\end{array}$ & $\begin{array}{l}+ \\
+\end{array}$ \\
\hline Tranter et al. (2009) & Carrots & $5 \mathrm{EU}$ & $\mathrm{CV}$ & $\begin{array}{l}\text { CG } \\
\text { Organic }\end{array}$ & $\begin{array}{l}+ \\
+\end{array}$ \\
\hline & Chicken & $5 \mathrm{EU}$ & $\mathrm{CV}$ & $\begin{array}{l}\text { CG } \\
\text { Organic }\end{array}$ & $\begin{array}{l}+ \\
+\end{array}$ \\
\hline Bougherara \& Combris (2009) & Orange Juice & France & BDM & ATCEP & + \\
\hline Scarpa et al. (2008) & Carrots & Italy & $\mathrm{HCE}$ & $\begin{array}{l}\text { Organic } \\
\text { BD } \\
\text { IPM }\end{array}$ & $\begin{array}{l}+ \\
+ \\
+\end{array}$ \\
\hline Lusk et al. (2007) & Pork & US & HCE & $\begin{array}{l}\text { EC } \\
\text { AWB } \\
\text { Free of Antibiotic }\end{array}$ & $\begin{array}{l}+ \\
+ \\
+\end{array}$ \\
\hline
\end{tabular}

NOTES: +: the label positively affects WTP; N.S.: no significant impact; HCE: Hypothetical choice experiment; RCE: Real choice experiment; SPLE: Stated preference in lab experiment; $C V$ : Contingent valuation; BDM: Becker-DeGroot-Marschak mechanism; USDA: United States Department of Agriculture; EU AW: European Union Animal Welfare; CF-20\%: Carbon footprint - 20\%; CF30\%: Carbon footprint - 30\%; Nkm: Number of kilometers; FFFP: Fair Flowers Fair Plants; STLR: Shoot Thinning and Leaf Removal; e-f: Eco-friendly; EF: Environmentally friendly; PDO : Protected designation of origin; PGI: Protected geographic indication; 5 EU: Denmark, Ireland, Italy, Portugal, and the United Kingdom; CG: Conversion-grade; ATCEP: Eco-label mentioning that agricultural techniques contribute to environmental protection; BD: Biodynamic production; IPM: Integrated pest management production; EC: Environmentally certified; AWB: Animal well-being 
a classification raises the question of the nature of the correlation between these private and public attributes. For such durable products as boilers and cars, energy consumption and $\mathrm{CO}_{2}$ emissions are positively correlated, which facilitates consumers' interest in the environment by the possible lower cost of using efficient products (Hahn \& Metcalfe, 2016). From an experiment with a virtual supermarket, Lacroix et al. (2017) studied how consumers choose a basket of foods among items signaled by traffic lights, with the majority of the offered products having incompatible nutritional and environmental qualities (e.g., a product having a green light for nutrition and a red light for the environmental impact). In such a context, the authors showed that such double labeling (i.e., nutrition/environment) is ineffective as consumers do not like to trade between the nutritional and environmental dimensions. Hence, several eco-labels not only focus on the environment, but also indicate the social, health, and animal welfare attributes, such as those dealing with sustainability (see Blackman et al., 2010). Indeed Grunert et al. (2014) found that sustainability labels (e.g., Rainforest Alliance, carbon footprint, Fair Trade, and animal welfare) do not play a major role in consumers' food choices.

The correlation may be imaginary when consumers believe that a private characteristic is positively correlated with the environment. For instance, Aertsens et al. (2009) and Mondelaers et al. (2009) underlined that the most important drivers of purchasing organic foods are the perception that the organic dimension is safer, healthier, and better for the environment than regular processes for producing food. However, there is little scientific evidence that eating organic products is healthier than eating regular products, with no significant differences in the chemical or pathogenic contaminations between regular and organic products (see Guéguen \& Pascal, 2010).

To summarize the empirical literature, many consumers want their products to be clean and their WTP for these clean products differs. A higher WTP for clean products than regular products spurs firms to use eco-labels. We now turn to the other side of the market by studying firms that aim to exploit the higher WTP for eco-friendly products.

\subsection{Firms' motivations}

Most eco-labels are voluntarily adopted by firms. For a firm, the choice of such a label is a strategic decision to inform consumers about the environmental attributes of its products. Hence, eco-labeling appears to be an opportunity to differentiate a firm's goods to improve sales (see Bonroy \& Constantatos, 2015, 2008). If consumers have a high WTP for highenvironmental quality goods and/or a low WTP for low-environmental quality goods, this would be a powerful incentive for firms to communicate through eco-labels and improve the environmental attributes of their products. The link between communication and environmental improvement is sometimes fragile and controversial. In particular, "greenwashing" involves making an outrageous environmental claim to conceal the lack of effort in improving the environment. This negative effect mainly depends on the seriousness of the certification 
process promoted either by private companies or independent certifying organizations (see the next section).

Any voluntary information that a firm adds to packaging aims to increase sales and boost profits (Golan et al., 2001). The theoretical models proposed by Arora \& Gangopadhyay (1995), Bagnoli \& Watts (2003), Amacher et al. (2004), Roe \& Sheldon (2007), Bottega \& De Freitas (2009), Bottega et al. (2009), and Bonroy \& Constantatos (2015) are significant contributions to studying firms' incentives to differentiate their products when consumers value certain environmental characteristics. These models rely on the crucial assumptions of vertical differentiation occurring when the offered goods are ordered according to their environmental quality from the highest to the lowest.

To provide a sense of the intuition behind these theoretical models, Figure 1 presents some of the key findings. This figure comes from a simple model described in the Appendix. It helps explain firms' incentives to select an eco-label under monopoly or duopoly. It is assumed that firms can choose either low-quality or high-quality products. The quality levels are given for simplicity, which differs from studies previously quoted. Without a certification providing this eco-label, they only produce low-quality products (see Akerlof, 1970). It is also assumed that one and/or two firms should pay sunk cost $C$ for perfectly certifying the high-environmental quality related to the eco-label (chosen in stage 2 of the model in the Appendix). Further, demand follows a vertical differentiation specification with price competition between firms (chosen in stage 3) (see Mussa \& Rosen, 1978). Firms' incentives to use certification and high-quality labeling are also presented in Figure 1 with high quality, $k_{h}$, represented on the $\mathrm{X}$-axis and certification cost $C$ represented on the Y-axis. Firms' choices are indicated in different areas. The $X$-axis starts at the low-quality level $k_{l}$, characterizing the lack of product differentiation. The higher $k_{h}$, the higher is the consumer's WTP for the high-quality product (see the Appendix).

Figure 1 shows that the voluntary selection of the label depends on the relative sizes of cost $C$ and high quality $k_{h}$, affecting the consumer's WTP. When cost $C$ is relatively low, the certification is affordable for one firm. When cost $C$ is relatively high, however, the prohibitive cost deters any firm from choosing the label. The higher quality $k_{h}$, the higher is the certification cost compatible with the selection of the label. Figure 1 underlines that the incentive to voluntarily certify depends on the number of competing firms for relatively mid-ranged certification costs, namely $C_{1}<C<C_{2}$. In this range, the incentive of a firm under duopoly is higher than that for one under monopoly. By certifying its products, the firm under duopoly reduces the intensity of the price competition with the other firm selecting low-quality products. In other words, certification allows firms to differentiate their products from competitors. Under duopoly with price competition, however, two firms cannot simultaneously certify their products because price competition would lead to zero gross profits, thus impeding the coverage of the sunk cost of certification. ${ }^{2}$ Although these

\footnotetext{
${ }^{2}$ This last result changes under quantity competition (Cornot) or with a marginal certification cost.
} 


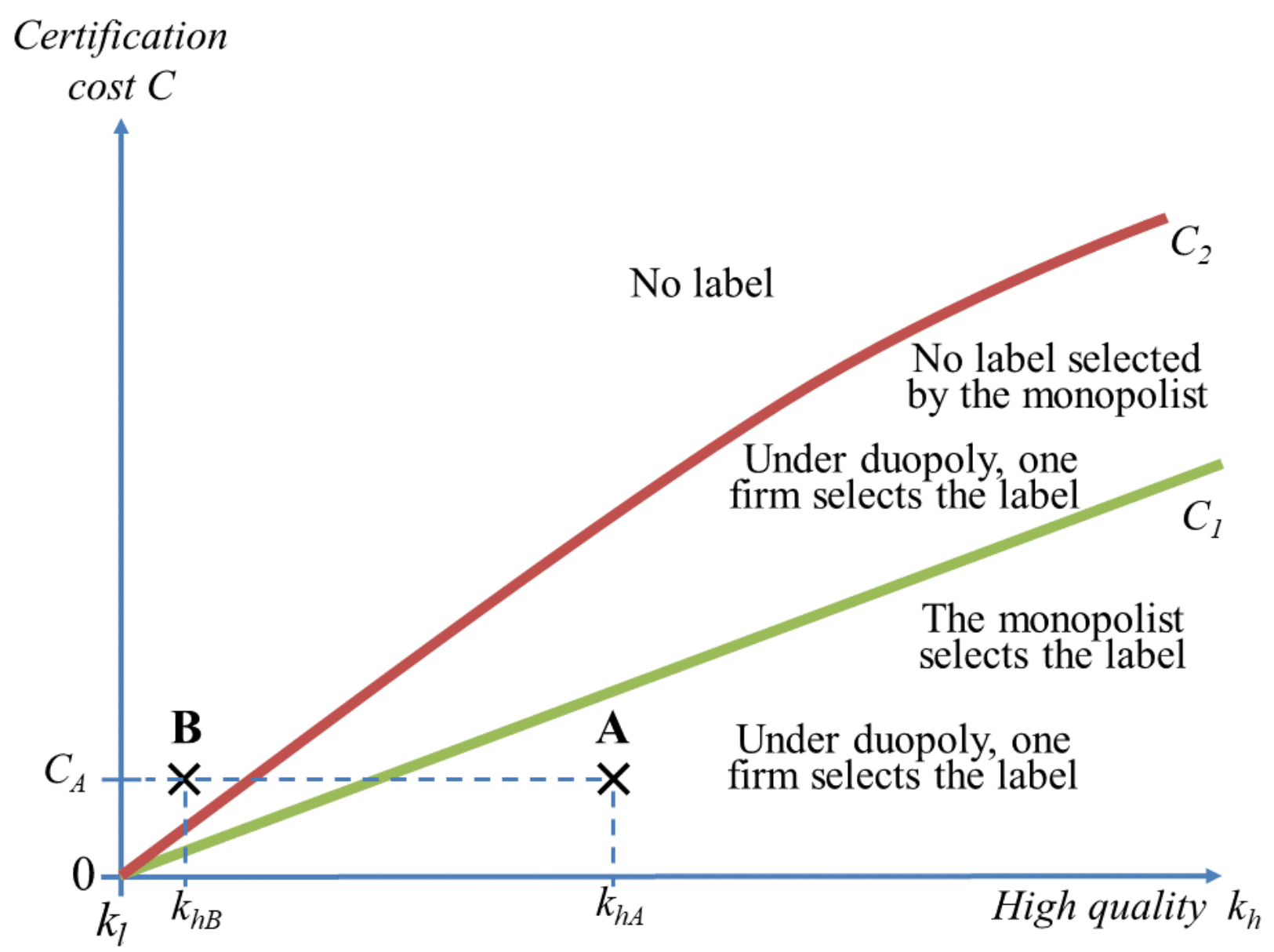

Figure 1: Voluntary selection of the high-quality label by firms under monopoly or duopoly 
assumptions are very simple, Figure 1 shows the importance of competition in the incentive to select an eco-label.

Beyond Figure 1, other contributions tackle important issues. The functioning of a supply chain promoting an eco-label and the contractual relationships inside such a supply chain have generally been overlooked in the literature. Among the exceptions, Bonroy \& Constantatos (2015) and Bonroy \& Lemarié (2012) theoretically examined downstream labeling and upstream price competition, underlining the complexity of the contractual links among the producers of a supply chain. Bonroy \& Lemarié (2012) showed that labels on the downstream market affects upstream price competition in the supply chain, with both differentiation and ranking effects determining who in the supply chain will receive the benefits and who will bear the burden of labelling. ${ }^{3}$ Recent econometrics studies have also considered supply chains with eco-labels. Using real purchase data identifying green and regular products, it is possible to develop a structural econometric model of demand and supply that takes into account the relationships between farmers and retailers. This structural econometric model allows researchers to distinguish between farmers' and retailers' margins, which is promising for understanding vertical relationships. Bonnet \& Bouamra-Mechemache (2016) computed the margins of regular and organic milk for retailers and manufacturers in France. They showed that per-unit margins in the organic sector are higher than those in the conventional sector. These methods are promising for evaluating the share of profits in the supply chain. This is particularly important as many supermarkets in Europe and the United States promote organic products to attract consumers with relatively high WTP. Hassan \& Monier-Dilhan (2006) studied firms' incentive to adopt a label when their brand reputation matters. For the same product, they underscored that the value of a label decreases when it is combined with another label or a well-known brand, as well as that retailers with supermarket brands often have a higher incentive to adopt a label than manufacturers with national brands.

This subsection underlined that firms' incentives to invest in eco-labels depend on several parameters influencing their profits, including the number of firms as shown in Figure 1. However, the fact that eco-labels are used by firms does not mean that market incentives have removed all the flaws and limitations, which are studied next.

\footnotetext{
${ }^{3}$ For firms, a voluntary eco-labeling approach can also be a way to anticipate and/or prevent public regulation that could be more constraining. Indeed, by complying with a certification process, firms try to reduce the environmental impact of their products and make consumers aware of their environmental attributes to demonstrate their goodwill as well as avoid more stringent regulation based on a norm or a tax. This dynamic aspect of regulation avoidance, although pervasive, is difficult to quantify. It seems that this topic is overlooked by the literature.
} 


\section{Limitations of eco-labels}

Eco-labels face several barriers to conveying credible information. Grunert (2011) highlighted six barriers limiting the impact of eco-labels on consumers' choices: the absence of consumers' perceptions of the label criteria, the peripheral broadcast of information about the label, the wrong inferences of the label meaning, the trade-off between an eco-label and an alternative label, the lack of awareness and/or credibility, and the lack of motivation at the time of choice.

The next three subsections present the potential limitations damaging the credibility of eco-labels. These three reasons lead to a decrease in the perceived quality of eco-labels, which reduces the incentive to certify in the first place. This case is illustrated in Figure 1, with the decrease in high-quality $k_{h}$ implying a shift from $k_{h A}$ (point A) to $k_{h B}$ (point B) at the same certification cost $C_{A}$. Hence, while an eco-label is worthwhile for the firm at point A, it becomes worthless for the firm at point B. We now describe the limitations that are particularly acute when we restrict our attention to eco-labels.

\subsection{Credibility of eco-labels}

Consumers' trust in voluntary eco-labeling is an important point, as sustainability characteristics are not directly visible by consumers before purchasing a product (Arguedas \& Blanco, 2013). Indeed, the environmental impacts of products are credence attributes (see Darby \& Karni, 1973), which means that consumers cannot be sure about the attributes even after consumption. Environmental impacts may be partially defined as experience attributes, which means that consumers can evaluate environmental attributes after purchase, as is the case with energy labels.

Third-party organizations, including private agencies and governments, contribute to the credibility of the messages on environmental attributes through criteria setting, certification, and enforcement (Dosi \& Moretto, 2001). With the possibility of illicit reporting regarding the environmental quality in the green market, Hamilton \& Zilberman (2006) show that fraud is less prevalent in green markets when entry barriers limit the number of firms, and classical environmental policies for limiting polluting techniques increase the incidence of fraud. They showed that markets characteristics and agents incentives influence the level of frauds coming from lax certifying agencies. Heyes \& Maxwell (2004),Van't Veld \& Kotchen (2011), Fischer \& Lyon (2014), and Fischer \& Lyon (2016) analyze the different motivations of NGOs, industry organizations and government for setting standards and inspections characterizing eco-labels.

Eco-label definitions can be contentious, with experts quibbling over criteria, as was the case with the Marine Stewardship Council label defining sustainable fishing ultimately judged as lenient and arbitrary by some scientists (Jacquet et al., 2010). 
The credibility of eco-labels for signaling high quality ultimately depends on whether consumers have faith in the third-party certifying agencies truthfully reporting their examination of firms adopting eco-labels. However, public and private certifying agencies cannot always perfectly determine quality at a reasonable cost or truthfully report the environmental impact of products. If a certification process is noisy and imperfect, polluting firms might be certified, whereas green firms might be rejected through the certification process (Mason \& Sterbenz, 1994). Further, if the certification process is too lenient, consumers may suspect greenwashing by firms Hamilton \& Zilberman (2006). Some contributions from the industrial organization field focus on the incentives of private certification agencies to truthfully report their observations of quality (Lizzeri, 1999). Competition among certifying agencies and the cost structure of the certification process play a crucial role in the incentive to reveal environmental quality (Crespi \& Marette, 2001; Auriol \& Schilizzi, 2015).

If consumers do not trust a label, it will have no impact on their purchase or their WTP. Consumers' trust may be influenced by diverse market issues including the complexity and profusion of eco-labels.

\subsection{Complexity and technicality of environmental information}

A multiplicity of eco-labels indicates different environmental dimensions (e.g., carbon footprint, greenhouse gas emissions, impact on the forest, use of pesticides, water consumption, biodiversity, energy consumption). Bruce \& Laroiya (2007) showed that increasing returns to scale and complexities in production imply that it will be possible to market only a small percentage of environmental attributes through the use of eco-labels. Regarding consumers, comprehension and memorization are acute issues when the information transmitted is technical and/or complex, as is the case for labels indicating $\mathrm{CO}_{2}$ emissions (Caputo et al., 2013b) and energy cost (Min et al., 2014). In the context of information overload, Keller \& Staelin (1989) and Wansink et al. (2004) found that if consumers have too much information, they lose the marginal effect of this information. With eco-labels, the challenge consists in conveying simple messages without betraying the complexity of environmental assessments. The puzzling question at the top of Figure 2 highlights the complexity of the various criteria related to eco-labels.

The rising number of environmental dimensions such as air pollution, water pollution, climate change, the use of pesticides, biodiversity protection, the development of renewable energies, and clean transportation is leading to a major difficulty in prioritizing consumption decisions in favor of the environment. This complexity is reinforced by the vast number of products that people can purchase, with each having complex environmental impact.

We know from the history of organic products that positive attitudes do not always translate into purchases (Thøgersen, 2000). Being positive toward sustainability at a general level does not necessarily mean that a consumer will purchase sustainable products Golan 
Do you know the specificity of each of these logos?
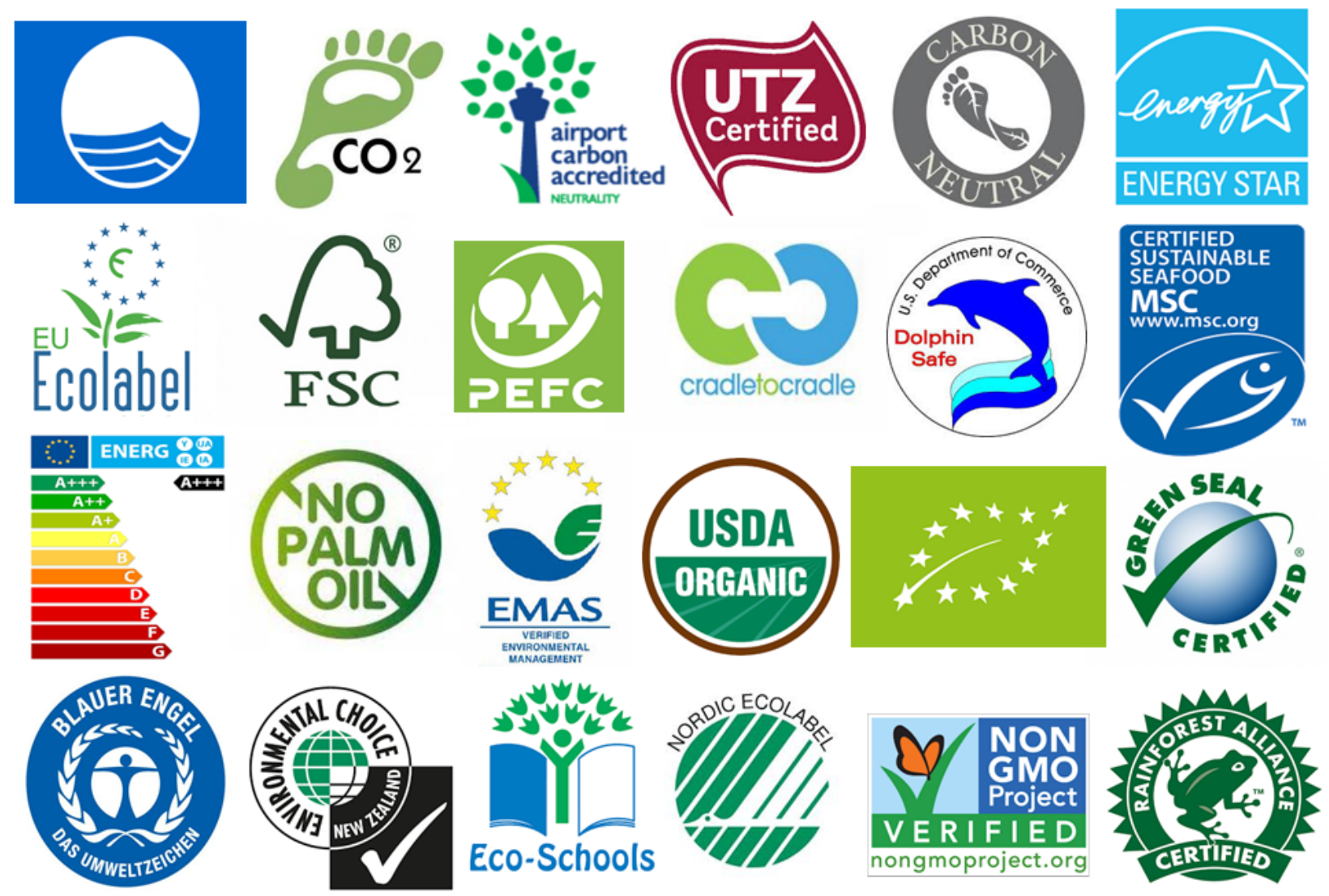

Figure 2: A few eco-labels 
et al. (2001). Consumers can be lost in a context with a large number of eco-labels only covering certain aspects of the broader sustainability concept. In addition to organic labels, there are alternative labels signaling environmental protection and others signaling fair trade, animal welfare, carbon footprint, local production, and other aspects.

Given that those issues limit the impact of eco-labels, researchers have aimed to improve the understanding of environmental labels (Vlaeminck et al., 2014). Providing information is insufficient; instead, general information/knowledge must be given to consumers (Grolleau et al., 2016). For carbon labels, the mode of communication is particularly important as it is possible to (1) directly reveal the amount of emissions for a product, (2) indicate these emissions on a graduated scale to allow comparison with other products, and (3) use a slogan such as "low carbon emissions" without any quantified indications. Despite efforts to simplify the messages, however, Kortelainen et al. (2016) found that having a carbon label has no impact on detergent prices and demand. Schubert (2017) underlines the social benefit of simplified labels/logos with injunctive messages that convey social approval or disapproval, using a smiley face to inform consumers who are characterized by imperfect recall and limited knowledge.

\subsection{The proliferation of eco-labels}

The chocolate bar market in Europe and in the United States epitomizes the current proliferation of labels trying to signal cocoa sustainability, with various practices for protecting soils and rainforests, reducing greenhouse gas emissions, and/or developing rural communities (see Rousseau, 2015). For instance, in France in 2017, the majority of national chocolate brands exhibited one or two labels in the following list: (1) the organic label (Agriculture Biologique), (2) the Fair Trade label (Max Havelaar), (3) the Rainforest label, (4) the Cocoa Plan label, (5) the Cocoa Life label, (6) the Carbon Neutral Product label, (7) the UTZ label, and (8) the Palm Oil Free label (see Marette, 2016). Many of these labels have similar criteria for signaling sustainability, which makes it difficult for consumers to distinguish the most efficient ones. Likewise, a new label called "Conversion to Organic" was recently created for French wine to signal the multitude of changes necessary to gain an organic label (current a two-year process) (Garbay, 2018). In the product segment, this label is located between conventional and organic products, thereby providing more diversity to consumers; however, it is also contributing to the possible confusion.

The proliferation of eco-labels leads to blurred signals. Indeed, in a study of carbon footprint labels, Gadema \& Oglethorpe (2011) showed that $89 \%$ of shoppers face confusion in interpreting and understanding labels because of poor communication and the proliferation of different labels. Brécard (2014) showed that the proliferation of eco-labels can significantly affect consumers' understanding of the environmental information they provide. Consumers might be confused as they do not know the specificity of each eco-label. In this context, they may give value to a label owing to its image at the expense of the intrinsic quality it 
guarantees and regardless of whether they perceive this label as a sign of environmental quality. Indeed, consumers may be more influenced by the marketing around a label than the environmental quality it represents. The proliferation of eco-labels thus leads to manifold claims about the health, environment, and/or sustainability effects, which limits the extent to which such labels help consumers (Marette, 2010).

Consumers' confusion impacts firms. Indeed, the profusion of eco-labels leads to a weakening of the value of the greenest eco-label in the minds of consumers. Other firms with alternative eco-labels related to low quality benefit from this confusion, and too many firms select low-quality eco-labels (Marette, 2010). Banerjee \& Solomon (2003) indicated that the multiplicity of voluntary labels for signaling energy efficiency also causes confusion among firms, which become uncertain about the best label to pursue. In an experiment for eliciting WTP and classifying the relevance of different labels posted on one product, Marette (2014) simulated the benefit a firm could obtain by reducing the number of labels on this product. This paper has shown that the exclusive use of the most valued label facilitates the recognition of this label, and has positive impact on WTP, profits and consumers' surplus.

To conclude, these limitations explain the fragile and weak performance of many ecolabels. Hence, regulation could try to improve the influence of eco-labels by overcoming some of these inefficiencies.

\section{Regulation with eco-labels}

The limitations of eco-labels underlined in the previous section raise some questions about the policy that could and should improve the environmental impact of various products. In many of the studies that define an optimal policy from a normative view, regulatory tools are selected by a policymaker aiming to maximize welfare, defined as the sum of the surpluses of its agents, including environmental damage.

\subsection{When and why to intervene}

In particular, the possible regulation linked to eco-labels was studied by Roe \& Sheldon (2007), Horne (2009), Disdier \& Marette (2012), Roe et al. (2014), and Messer et al. (2017). The approach in Figure 1 can be used to explain when a regulator should intervene. The regulator can take actions by maximizing welfare (chosen in stage 1 of the model in the Appendix). It is assumed that the regulator can impose a mandatory label or subsidize the certification cost if a mandatory label is not possible.

The regulator maximizing welfare may intervene to correct certain voluntary decisions. Figure 3 starts from Figure 1 by only focusing on monopoly. It presents the choices for maximizing welfare in a monopoly market. These choices do not correspond to the choice of the monopolist for relatively medium-sized certification costs, namely $C_{1}<C<C_{3}$. As 


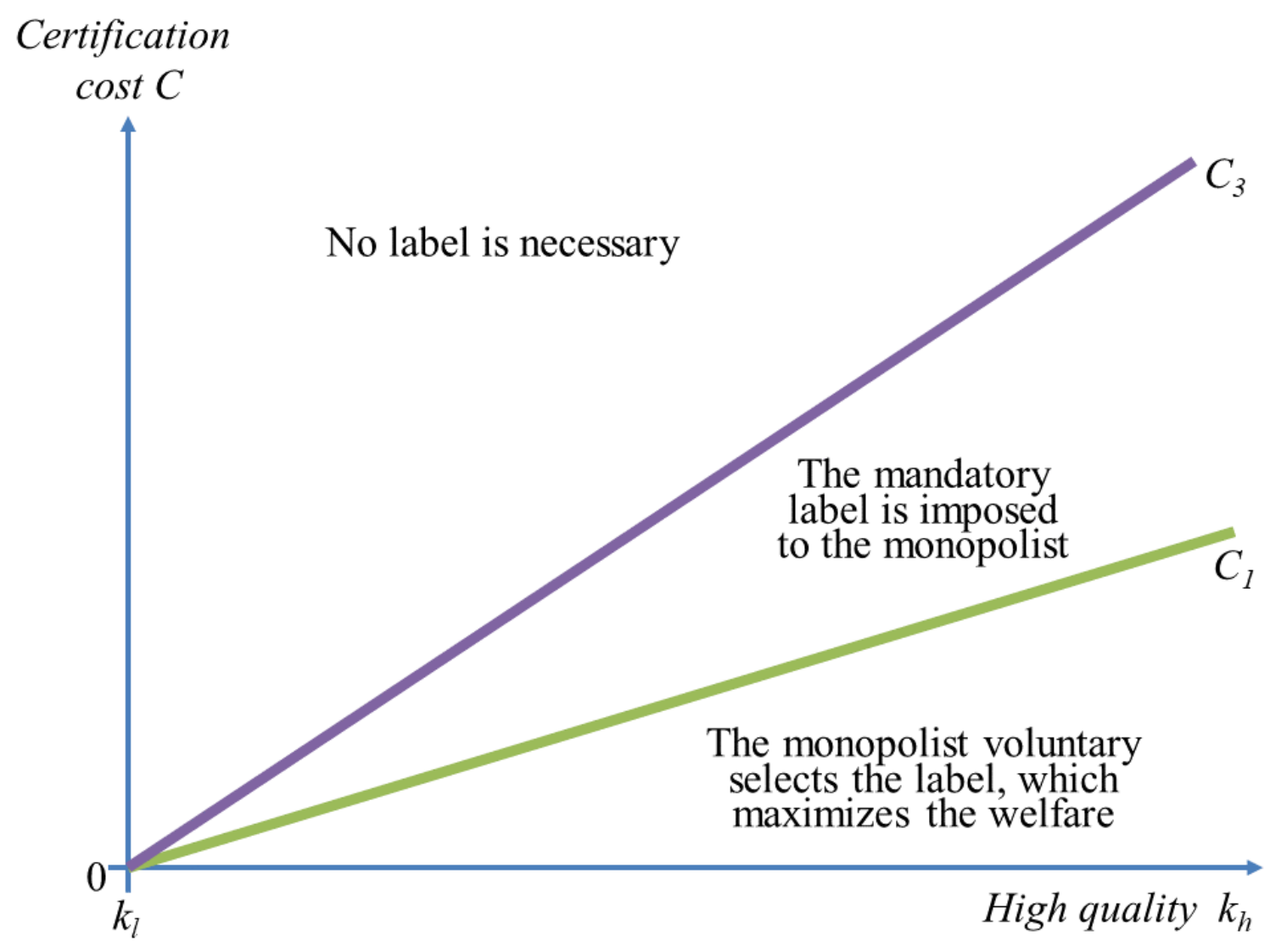

Figure 3: Welfare and a high-quality label under monopoly

the sunk cost of certification is not passed via the market price onto consumers, who do not internalize this cost in their demand, the firm's choices differ from those that would maximize welfare. When $C_{1}<C<C_{3}$, the regulator imposes a mandatory label on the firm. This certification cost typically related to mandatory labeling can be borne by the monopolist, with gross profits higher than the certification cost. Figure 3 shows that the market incentives are not always sufficient for favoring the emergence of eco-labels. In this simplified analysis, we do not take into account the new distortions that may result from mandatory labeling (see Roe et al., 2014). We do not have any over-compliance that could emerge if a firm wants to differentiate its products from other products complying with the mandatory label (see Arora \& Gangopadhyay, 1995).

Figure 4 starts from figure 1 by only focusing on duopoly. Figure 4 presents the choices for maximizing welfare under a duopoly. Once again, as the sunk cost of certification is not passed onto consumers, the firm's choices differ from those that would maximize welfare for two areas. First, for $C<C_{4}$, the choice maximizing welfare is to fully subsidize the certification cost to ensure that the label is selected by both firms, and to impose a highquality standard banning low-quality. A mandatory label would be impossible to implement because both firms with high-quality products would have zero gross profits under price competition, impeding the coverage of the certification cost. Such a mandatory label would then lead to the exit of one firm. However, fully subsidizing the certification cost for both firms 


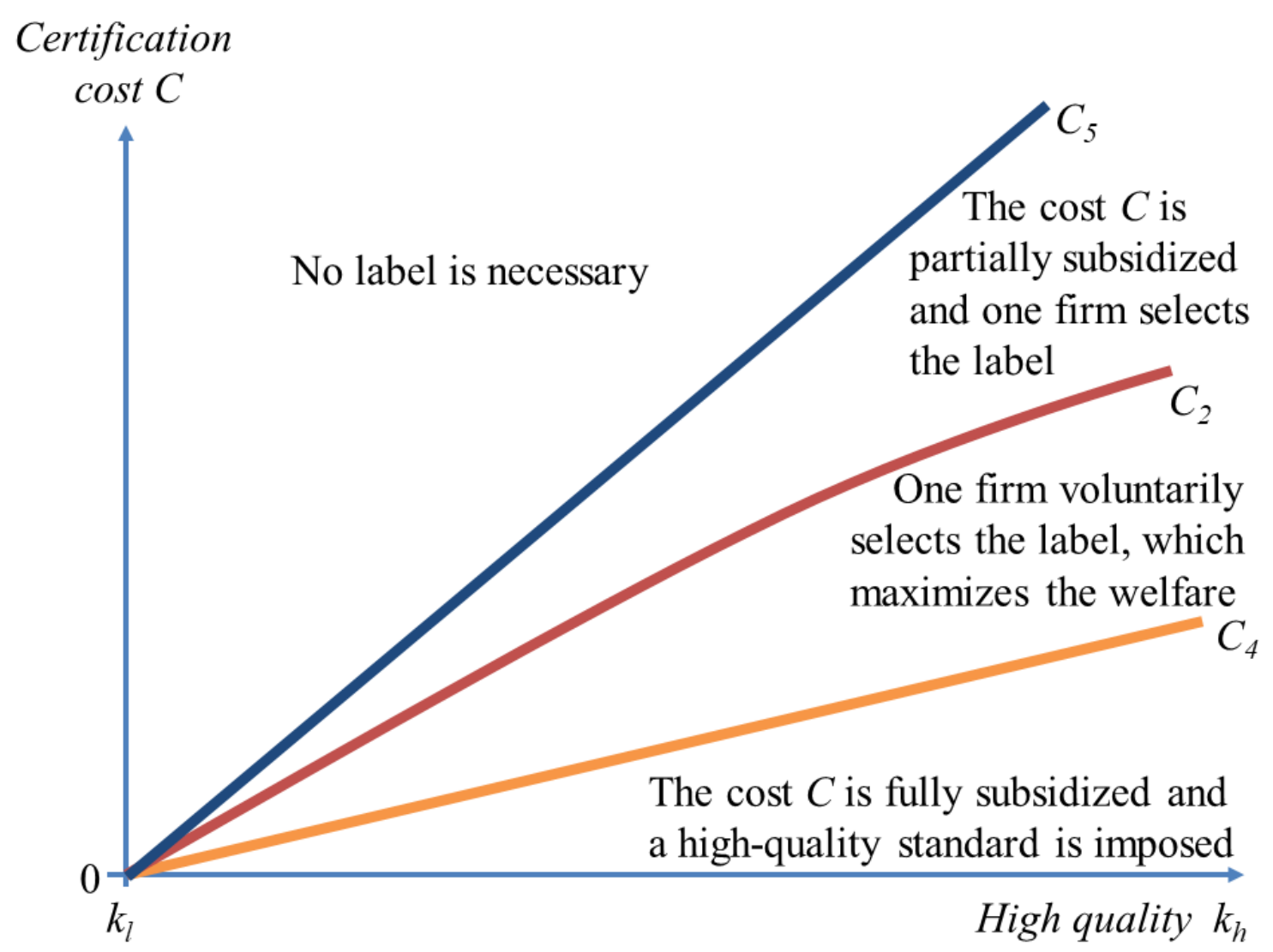

Figure 4: Welfare and a high-quality label under duopoly

could be difficult when the opportunity cost of public funds is high, a case not considered in our simplified model. This result is specific to a duopoly under price competition.

Second, for $C_{2}<C<C_{5}$, the regulator certifies one firm, while the other one offers lowquality products. No mandatory label can be implemented, as the choice of different qualities is socially optimal. A partial subsidy propelling one firm to certify its high-quality products is thus selected (see the Appendix). Note, however, that we do not study the configuration in which the regulator could lead one firm to exit the market by imposing a mandatory label under duopoly with price competition. Despite these simple assumptions, Figures 3 and 4 underline that regulatory intervention crucially depends on the number of firms. Both figures invalidate the idea that firms resort to voluntary labeling whenever markets have incentives to supply labels. By also considering consumers, the regulator may influence decisions for medium-sized certification costs.

Beyond Figures 3 and 4, other contributions tackle important issues. We now provide more details on the regulatory possibilities that could improve the efficiency of eco-labels by taking account of the limitations of these eco-labels underscored in the previous section 


\subsection{Improving the efficiency of voluntary eco-labels}

Regarding the previously exposed limitations of eco-labels, a regulator might decide whether to intervene to increase the efficiency of voluntary eco-labeling. Without imposing any mandatory actions on firms, it may attempt to influence firms' incentives to voluntarily adopt an eco-label. A regulator is particularly useful for setting up a common signal with a clear specification for producers and consumers (Crampes \& Hollander, 1995). As the proliferation of eco-labels comes from the diversity of the environmental attributes such as greenhouse gas emissions, biodiversity, land use, water consumption, and chemical pollution, playing on the number of environmental attributes signaled by eco-labels can be an option for a regulator. Indeed, a government may encourage the creation of global environmental labels encompassing several attributes or it may limit the number of eco-labels for a given attribute.

Green characteristics require a clear definition specific to an eco-label to persuade consumers. Providing generic explanations and recommendations on the impact of clean consumption could be useful for developing consumers' knowledge and sensitivity, but this is not a panacea for changing behaviors. Generic advertising that offers greater explanation has a limited impact on attracting consumers' attention to eco-labels (Chen et al., 2015). The regulator should thus ban false claims and inspect certifying agencies that guarantee the credibility of eco-labels. The questions of both credibility and public monitoring are acute as scientific experts have previously criticized the poor environmental impacts of voluntary certification in the fisheries, palm oil, and textiles sectors (see Changing Markets Foundation, 2018).

Understanding firms' incentives to adopt an eco-label can be a thorny issue for a regulator because of the lack of knowledge about firms' costs and markets' specificities (see Amacher et al., 2004). Firms have interactions as well with NGOs. Since to be relevant an eco-label need to be used by companies, creating new eco-labels, NGOs interact with private sector to ensure that some companies can reach the specifications of their labels. As well, pressure by NGOs often leads firms to replace components harmful for the environment with ecofriendly substitutes signaled by an eco-label (Brécard \& Chiroleu-Assouline, 2018). Goals such as pollution reduction and welfare improvement via the promotion of one or several eco-labels require inefficient firms to exit the market or, at the very least, low market shares for unlabeled products. Benoit et al. (2015) raised the issue of increasing the market share of food with organic labels to limit the prevalence of pesticides. These higher market shares could be reached by providing subsidies, as mentioned in Figure 4. Such a policy may lead to unexpected consequences, however, because the withdrawal of pesticides decreases crop yields and ultimately increases food prices.

Another option consists in understanding the impact of competition coming from the presence of different types of labels (see Li \& van 't Veld, 2015; Brécard \& Chiroleu-Assouline, 2018). Fischer \& Lyon (2014) study competition between a NGO and an industry that can establish their own voluntary standard with a related label signaling it. They found that 
environmental benefits may be smaller with two competing labels than with the NGO label alone, and they show that this label competition is not systematically environmentally beneficial. A regulator could also choose to limit eco-labeling in the market by capping the number of eco-labels that one owner is allowed to create, thereby increasing the requirements for introducing new labels, or normalizing a maximum number of eco-labels existing by categories of goods and services.

When consumers cannot precisely ascertain the environmental quality related to different labels, the regulator faces a trade-off between the promotion of a single label with harmonized environmental criteria and competition among different eco-labels, which risks confusion in the market owing to the heterogeneity of consumers' preferences (Golan et al., 2001). The question of satisfying the heterogeneity of consumers' preferences has been tackled by research studying the development of an intermediate environmental label between regular and organic products (see Marette et al., 2012; van Herpen et al., 2015). Indeed, if the regulator and certifying organizations want to favor harmonized certification under a single label, they must determine the stringency of the environmental certification to maximize welfare. In particular, the high environmental quality related to this single label may oust many competitors tempted to create an alternative label that would ultimately lead to a possible proliferation. All these market reactions challenge the regulator's ability to efficiently promote voluntary eco-labels for reducing pollution.

As we have argued that influencing the adoption of voluntary labels is a thorny issue, the regulator may turn to the enforcement of a mandatory eco-labeling, which is studied next.

\subsection{The relevance of mandatory eco-labeling}

The regulator may want to force firms to disclose environmental information because it is a right for consumers to be aware of certain attributes (Golan et al., 2001). Figures 3 and 4 show that imposing a mandatory label is not systematic and rather depends on the market structure.

Figure 5 shows an example of a mandatory eco-label imposed at the European Union (EU) level when consumers purchase a car. This eco-label combines traffic lights with quantified details about emissions. This mandatory system is also used for other durable goods sold in the EU. Such a mandatory labeling policy is rarely only motivated by the environmental issue, such as the case of the mandatory energy consumption labeling implemented for decades in the United States and Europe. This label classifies the energy consumption of goods using electricity. Each class is described by a letter and a color to be easily understandable by all consumers. Such an eco-label informs consumers about energy consumption as well as the consequences in terms of consumers' cost, energy wastage, and the environment Min et al. (2014).

Before deciding to enforce a mandatory label, the regulator should be careful about the 


\begin{tabular}{|c|c|}
\hline Vehicle Information & \\
\hline \multicolumn{2}{|l|}{$\mathrm{CO}_{2}$ emission figure $(\mathrm{g} / \mathrm{km})$} \\
\hline$\leqslant 120$ & $104 \mathrm{~g} / \mathrm{km}$ \\
\hline \multicolumn{2}{|l|}{$120+$ to $140 \mathrm{~B}$} \\
\hline \multicolumn{2}{|l|}{$140+$ to 155} \\
\hline \multicolumn{2}{|l|}{$155+$ to 170} \\
\hline \multicolumn{2}{|l|}{$170+$ to 190} \\
\hline \multicolumn{2}{|l|}{$190+$ to 225} \\
\hline \multicolumn{2}{|l|}{$225+$} \\
\hline $\begin{array}{l}\text { Fuel Use (estimated) for } 18,000 \text { kilometres } \\
\text { A fuel use figure is indicated to the consumer as a guide for comparison purposes. This figure is } \\
\text { calculated by using the combined drive cycle (urban and extra urban fuel consumption cycles). }\end{array}$ & 774 litres \\
\hline $\begin{array}{l}\text { Motor Tax for } 12 \text { months } \\
\text { Motor Tax varies according to the } \mathrm{CO}_{2} \text { emissions of the vehicle. }\end{array}$ & $€ 100$ \\
\hline $\begin{array}{l}\text { Vehicle Registration Tax (VRT) Rate } \\
\text { Percentage rate of VRT payable of the value of the vehicle is dependant on } \\
\text { the } \mathrm{CO}_{2} \text { emissions. }\end{array}$ & $14 \%$ \\
\hline $\begin{array}{l}\text { Environmental Information } \\
\text { A guide on fuel economy and } \mathrm{CO}_{2} \text { emissions which contains data for all new passenger } \\
\text { point of sale free of charge or directly from the Society of the Irish Motor Industry, } 5 \text { Upp } \\
\text { Tel: } 01-6761690 \text {, web address: www.simi.ie. In addition to the fuel efficiency of a car, driv } \\
\text { other non-technical factors play a role in determining a car's fuel consumption and } \mathrm{CO}_{2} \\
\text { greenhouse gas responsible for global warming. }\end{array}$ & $\begin{array}{l}\text { dels is available at any } \\
\text { broke Street, Dublin } 2 \text {, } \\
\text { naviour as well as } \\
\text { ns. } \mathrm{CO}_{2} \text { is the main }\end{array}$ \\
\hline
\end{tabular}

Figure 5: Mandatory eco-label for $\mathrm{CO} 2$ emissions by vehicles in France 
nature of the product. It must take into account the clearness of the information conveyed by the eco-label to avoid consumers' confusion. It should also assess the effects of labeling costs on the market (Crespi et al., 2003). An advantage of eco-labeling is its credibility because it is imposed and controlled by the public regulator. Generally, as the regulator endorses the cost of setting up the eco-labeling system and monitoring all firms, a mandatory ecolabeling system is more expensive for the government than the inspection of a voluntary eco-labeling system. From a policy point of view, eco-labels help inform consumers about the environmental attributes of all the products sold in the market. In the case of goods with negative credence attributes, firms have no incentive to voluntarily eco-label their goods, which is a major motivation for justifying a mandatory eco-label. From a natural experiment with a mandatory traffic light system signaling the environmental sustainability of fish sold in California, Hallstein \& Villas-Boas (2013) underlined that the sales of fish with a amber light were negatively impacted, while the sales of sustainable fish with a green light were not. They showed that the mandatory traffic light system led to a significant $15.3 \%$ decline in overall fish sales.

When a certain attribute is mandated by law to be labeled, consumers might perceive it as a subtle signal from the government to be cautious about the criteria to favor favoring producers' acceptance or consider it to be an inferior product, which in turn affects their preferences. This signaling effect goes beyond the simple informational effect. Considering this effect, a mandatory labeling policy may have a strategic dimension not recognized in the previous literature. In a lab experiment, (Bansal \& Ramaswami, 2010; Bansal et al., 2013) attempted to delineate the frontier between the signaling effect of a label and the informational effect. They found that the informational effect dominates the signaling effect. Messer et al. (2017) pointed out that mandatory labels are likely to have serious unintentional consequences such as consumers' misinterpretations of these labels and/or the stigmatization of low-quality products. This is particularly acute when mandatory standards are not based on science evidences. Tian (2004) found that mandatory eco-labels can impede the entry of firms or lead some to exit the market. ${ }^{4}$

All these market adjustments should be taken into account by a regulator when deciding whether a mandatory eco-label should be enforced.

\subsection{Eco-labels compared with other policy instruments}

Mandatory eco-labels are interesting for allowing freedom of choice among diverse products and encouraging consumers with higher WTP to buy cleaner products. However, as

\footnotetext{
${ }^{4}$ Some studies (Nimon \& Beghin, 1999b; Joshi, 2004; Sheldon et al., 2009; Roe et al., 2014) have examined the impacts of voluntary and/or mandatory eco-labeling programs on international trade. Eco-labels highlighting environmental characteristics may boost high-value exports from poor countries, which is positive for trade, or impede poor countries from entering certain markets because of the costly requirements linked to certification, which is negative for trade.
} 
underlined in previous sections, limitations, including the lack of recognition and knowledge about eco-labels, impede many consumers from internalizing the characteristics signaled by eco-labels. Therefore, the advantages and shortcomings of eco-labels should be compared with those of other regulatory tools.

Regarding environmental policy, the regulator often chooses command and control instruments such as norms and taxation. Norms and standards impose on producers a minimum level of quality or a specific production process that facilitates trade. However, minimum-quality standards may have the drawbacks of reducing the diversity of products, by eliminating low quality, which is however a legitimate objective when both health and safety matter for society. The mechanism of taxation and/or subsidy is a regulatory alternative based on the price impact on consumers' choices as prices are affected by the tax/subsidy per unit sold (Marette et al., 2008). The low elasticity of product demand in relation to prices limits the impact of the price variations induced by tax/subsidies on the quantities consumed. Every tool entails distortions that should be taken into account.

As shown by Goulder \& Parry (2008) and Disdier \& Marette (2012), economic analyses do not provide any definitive conclusions on the optimal use of these tools. Although eco-labels could provide information to consumers, other tools would still be useful as all externalities cannot be internalized by some consumers. Regulation is useful, because market imperfection may lead to an excess of quality differentiation compared with what is socially optimal (Bansal \& Gangopadhyay, 2003). Birg \& Voßwinkel (2018) theoretically showed that social welfare is higher under the combination of both minimum quality standards and mandatory labeling than under either no regulation or each instrument applied in isolation.

Because of their lack of recognition by consumers with limited recall, eco-labels do not provide perfect information and environmental characteristics are not fully internalized. Eco-labels can thus be associated with other policy instruments such as standards banning/limiting non-green products, taxes on non-green products, and/or subsidies on green products. From a welfare perspective, Disdier \& Marette (2012) and Walter \& Chang (2017) argued that the combination of eco-labels and other instruments is socially optimal. Indeed, Horne (2009) argued that eco-labels alone are insufficient. Eco-labels should thus be considered to complement standards banning/limiting non-green products and taxes/subsidies on green products. Such a combination of tools may overcome some of the shortcomings presented above, although the unnecessary redundancy of tools is a burden for society. Applied estimations are thus useful for evaluating policies on a case-by-case basis.

The evaluation of a policy on a case-by-case basis should compare all regulatory tools by taking into account all the limitations presented in previous sections and by eliciting consumers' preferences for the various environmental characteristics of a given product. Ideally, empirical economic analysis would entail monetizing all the relevant environmental dimensions, which implies, among other factors, assessing the positive and negative environmental externalities of the production process. These evaluations are often conducted using 
stated or revealed preference methods focusing on a specific outcome, without accounting for the potential conflicts among environmental issues. Cost/benefit analysis aggregates the various dimensions of environmental sustainability into a single monetary value. The WTP for a good/characteristic may vary depending on whether it is evaluated on its own or as part of a broad basket of goods/characteristics, which ultimately raises the question of the stability of WTP. Kahneman \& Knetsch (1992) underlined the sub-additivity effect that occurs when the estimated WTP for the improvement of one characteristic plus the estimated WTP for another characteristic is greater than the "common WTP" when participants are asked to value the two characteristics together. The cost/benefit analysis should address these methodological limitations to determine the optimal combination of an eco-label, a standard, and/or a tax/subsidy mechanism.

\section{Conclusion and future research perspectives}

The previous sections presented the main findings of prior studies on eco-labels. In particular, we underlined the limitations of eco-labels for conveying complex information to consumers. The relevance of eco-labels for conducting environmental policy can differ among countries, depending, for example, on the attention paid to information on the sustainable and environmental dimensions by local consumers.

We identified several overlooked issues that seem important to study in the future.

1. Regarding consumers, many theoretical models or experiments only focus on one type of product (e.g., tomatoes) and the different quality levels of a specific product. However, these approaches do not explain the environmental aspect of the whole basket of goods and services purchased by each consumer. If you consider the whole basket of products, each person may favor eco-labels for some products and neglect eco-labels for others because of budget constraints and/or the slackening of the "green effort" after the consumption of green goods that are relatively expensive. In other words, a self-licensing effect may exist, increasing the self-confidence of consumers buying a few green products and tending to make them less worried about the consequences of buying other polluting products. Considering the basket of all purchased products raises the question of the eco-label of this basket rather than the eco-label of a given product. An eco-label for a basket is tricky to define because of the complex substitutions between green and non-green products made by consumers. More research should thus be conducted to understand these types of eco-labels for the whole basket.

2. Regarding consumers, scanning barcodes with smartphones may provide a large amount of information on the environmental performance of various products. These exhaustive messages may complement the eco-labels posted on products, or even replace them. New discounts that depend on the search for eco-labels could be offered for interested consumers. However, the number of consumers searching for environmental 
information on green/non-green products is unclear.

3. Regarding firms and the regulator, many studies in industrial organization and regulatory economics only examine the static aspect of exchanges, investment, and regulation by considering one period. The dynamic aspect of the presence of an eco-label is generally overlooked. An eco-label may open a window for future regulation that would be more stringent, such as one justifying a minimum quality standard that maximizes welfare . It is possible to extend the analysis by integrating dynamic configurations with repeated exchanges in markets, the possibility of exiting/entering a market, and the possibility for a label to lose a good reputation.

4. From a regulatory point of view, the previous section showed that no regulatory instrument clearly dominates consumers' choices when welfare maximization is the objective. The eco-label may be efficient or unknown depending on many parameters, including the proliferation that hampers clear messages. The impact of eco-labels and alternative instruments on both the environment and welfare should thus be realized on a case-by-case basis. Cost/benefit analyses should be more often made on a product-byproduct basis to understand the optimal welfare choices. This is particularly the case for deciding whether a mandatory eco-label should be imposed. Depending on the cost of inspecting firms, the policymaker must determine the number of inspections for domestic and foreign firms, the penalty for non-compliance, and the way to finance such a policy. The social benefits of imposing a mandatory label would be diminished by taking into account the cost of regulation. An analysis on a product-by-product basis would therefore combine empirical estimations of WTP with models detailing the market mechanisms.

5. From a regulatory point of view, few studies quantify the impact of eco-labels on the environment. Among the exceptions, Blackman et al. (2018) precisely estimated the effect of Forest Stewardship Council eco-labels on deforestation in Mexico. Despite their impressive work that considered many indicators, however, they were unable to reject the null hypothesis that certification does not affect deforestation. This work illustrates the difficulty of quantifying the influence of eco-labels on the environment because of the complexity of environmental effects, heterogeneity of economic situations, and data availability. More work should be carried out on this topic.

6. Further research might also be conducted to assess the effect of eco-labeling on the incentives for technological innovation and investment in the research and development of cleaner technologies. As there is demand for more sustainable products and an incentive for firms to provide greener goods and services, it is relevant to observe how eco-labels contribute to green innovation.

7. Eco-labels could be coupled with other labels signaling quality, safety, or health benefits. In many cases, eco-labels improve environmental quality and thus, have an indirect effect on animal and human health locally. Being aware of these indirect benefits of a clean environment on health could increase the demand for products with eco-labels. 
This raises the complex question of precise indicators signaling all characteristics versus a simplified label displaying a synthetic grading accounting for all these dimensions.

8. A large amount of empirical evidence is from developed countries, as shown in Table 1. As eco-labels are often nascent in developing countries, there is little empirical evidence on WTP for environmental attributes in these nations. More evidence on the likely expansion of eco-labels in developing countries should be provided.

9. We noted a lack of studies of the nascent use of eco-labels by public services or local authorities. For instance, the Airport Carbon Accreditation is an institution providing a certification of the carbon management of airports, which is a complex issue for airports with high levels of pollution (see Airport Carbon Accreditation, 2019). Beyond this example, the incentive for a local government to certify/label its public activities can be limited if inhabitants are not sensitive to these questions and/or not ready to move toward green cities. An interesting extension could consist of developing a kind of Tiebout model in which competition across cities places competitive pressure on the provision of local public goods, such that the optimal level of public goods could emerge (Tiebout, 1956). Indeed, with such a Tiebout (1956) approach, green labels for cities could signal green public amenities, attract interested citizens, and contribute to the emergence of the optimal level of environmental public goods.

Beyond these overlooked questions, the economic literature underlines that an eco-label is useful but imperfect for providing information. An economic approach accounting for behaviors and incentives is appropriate to complement classical studies of environmental policy, which are generally defined by ecological, toxicological, and/or epidemiological objectives aimed at improving the environment. By taking into account the different effects underscored in this paper, economic approaches should lead to cost/benefit analyses that help debates and public decision-making.

\section{Acknowledgments}

We thank the two reviewers for their comments and the editor for his support. This paper was funded by the project DIETPLUS ANR-17-CE21-0003 financed by the French National Agency for Research (ANR). 


\section{References}

Aertsens, J., Verbeke, W., Mondelaers, K., \& Huylenbroeck, G. V. (2009). Personal determinants of organic food consumption: a review. British Food Journal, 111(10), 1140-1167.

Airport Carbon Accreditation (2019). Available at https://www. airportcarbonaccreditation . org/. Access January 2019.

Akerlof, G. A. (1970). The market for "lemons": Quality uncertainty and the market mechanism. The Quarterly Journal of Economics, 84(3), 488-500.

Amacher, G. S., Koskela, E., \& Ollikainen, M. (2004). Environmental quality competition and eco-labeling. Journal of Environmental Economics and Management, 47(2), 284 - 306.

Andreoni, J. (1990). Impure altruism and donations to public goods: A theory of warm-glow giving. The economic journal, 100(401), 464-477.

Aprile, M., Caputo, V., \& Nayga, R. (2012). Consumers' valuation of food quality labels: The case of the european geographic indication and organic farming labels. International Journal of Consumer Studies, 36(2), 158-165.

Arguedas, C. \& Blanco, E. (2013). Corporate environmental responsibility, consumers trust and imperfect competition. European Association of Environmental and Resource Economists.

Arora, S. \& Gangopadhyay, S. (1995). Toward a theoretical model of voluntary overcompliance. Journal of Economic Behavior E Organization, 28(3), 289 - 309.

Auriol, E. \& Schilizzi, S. G. (2015). Quality signaling through certification in developing countries. Journal of Development Economics, 116, 105 - 121.

Bagnoli, M. \& Watts, S. G. (2003). Selling to socially responsible consumers: Competition and the private provision of public goods. Journal of Economics E Management Strategy, 12(3), 419-445.

Banerjee, A. \& Solomon, B. D. (2003). Eco-labeling for energy efficiency and sustainability: a meta-evaluation of us programs. Energy Policy, 31(2), $109-123$.

Bansal, S., Chakravarty, S., \& Ramaswami, B. (2013). The informational and signaling impacts of labels: experimental evidence from india on gm foods. Environment and Development Economics, 18(6), 701-722.

Bansal, S. \& Gangopadhyay, S. (2003). Tax/subsidy policies in the presence of environmentally aware consumers. Journal of Environmental Economics and Management, 45(2), 333-355.

Bansal, S. \& Ramaswami, B. (2010). Labels for gm foods: What can they do? Economic and Political Weekly, (pp. 167-173). 
Benoit, M., Tchamichian, M., Penvern, S., Savini, I., \& Bellon, S. (2015). Le Bio peut-il nourrir le monde? Technical report. Working paper. Les 9es journées de recherches en sciences sociales INRA UMRH SFER CIRAD, Clermont-ferrant 10-11.

Birg, L. \& Voßwinkel, J. S. (2018). Minimum quality standards and compulsory labeling when environmental quality is not observable. Resource and Energy Economics, 53, 62-78.

Bjørner, T. B., Hansen, L. G., \& Russell, C. S. (2004). Environmental labeling and consumers' choice-an empirical analysis of the effect of the nordic swan. Journal of Environmental Economics and Management, 47(3), $411-434$.

Blackman, A., Goff, L., \& Planter, M. R. (2018). Does eco-certification stem tropical deforestation? forest stewardship council certification in mexico. Journal of Environmental Economics and Management, 89, $306-333$.

Blackman, A., Rivera, J., et al. (2010). The evidence base for environmental and socioeconomic impacts of" sustainable" certification. Discussion Paper-Resources for the Future (RFF), (10-17).

Blend, J. R. \& van Ravenswaay, E. O. (1999). Measuring consumer demand for ecolabeled apples. American Journal of Agricultural Economics, 81, 1072.

Blue Flag (2018). Available at http: //www . blueflag.global/ accessed on August 2018.

Bonnet, C. \& Bouamra-Mechemache, Z. (2016). Organic label, bargaining power, and profitsharing in the french fluid milk market. American Journal of Agricultural Economics, 98(1), 113-133.

Bonroy, O. \& Constantatos, C. (2008). On the use of labels in credence goods markets. Journal of Regulatory Economics, 33(3), 237-252.

Bonroy, O. \& Constantatos, C. (2015). On the economics of labels: How their introduction affects the functioning of markets and the welfare of all participants. American Journal of Agricultural Economics, 97(1), 239-259.

Bonroy, O. \& Lemarié, S. (2012). Downstream labeling and upstream price competition. European Economic Review, 56(3), 347 - 360.

Bottega, L. \& De Freitas, J. (2009). Public, private and nonprofit regulation for environmental quality. Journal of Economics \& Management Strategy, 18(1), 105-123.

Bottega, L., Delacote, P., \& Ibanez, L. (2009). Labeling policies and market behavior: quality standard and voluntary label adoption. Journal of Agricultural \& Food Industrial Organization, $7(2)$.

Bougherara, D. \& Combris, P. (2009). Eco-labelled food products: what are consumers paying for? European Review of Agricultural Economics, 36(3), 321-341. 
Brécard, D. (2014). Consumer confusion over the profusion of eco-labels: Lessons from a double differentiation model. Resource and Energy Economics, 37, 64 - 84.

Brécard, D., Hlaimi, B., Lucas, S., Perraudeau, Y., \& Salladarré, F. (2009). Determinants of demand for green products: An application to eco-label demand for fish in europe. Ecological Economics, 69(1), 115 - 125.

Brécard, D. \& Chiroleu-Assouline, M. (2018). Component-free strategy of firms under pressure from the NGOs. Technical report. Working paper. University of Toulon, France.

Bruce, C. \& Laroiya, A. (2007). The production of eco-labels. Environmental and Resource Economics, 36(3), 275-293.

Caputo, V., Nayga, R. M. J., \& Scarpa, R. (2013a). Food miles or carbon emissions? Exploring labelling preference for food transport footprint with a stated choice study. Australian Journal of Agricultural and Resource Economics, 57(4).

Caputo, V., Vassilopoulos, A., Jr., R. M. N., \& Canavari, M. (2013b). Welfare Effects of Food Miles Labels. Journal of Consumer Affairs, 47(2), 311-327.

Changing Markets Foundation (2018). The false promise of certification. Available at http://changingmarkets.org/wp-content/uploads/2018/05/False-promise_ full-report-ENG.pdf accessed on August 2018.

Chen, X., Alfnes, F., \& Rickertsen, K. (2015). Consumer preferences, ecolabels, and effects of negative environmental information. AgBioForum, 18(3), 327-336.

Costa, S., Ibanez, L., Loureiro, M. L., \& Marette, S. (2009). Quality promotion through ecolabeling: introduction to the special issue. Journal of agricultural $\mathcal{E}$ food industrial organization, $7(2)$.

Crampes, C. \& Hollander, A. (1995). How many karats is gold: Welfare effects of easing a denomination standard. Journal of Regulatory Economics, 7(2), 131-143.

Crespi, J. M. \& Marette, S. (2001). How should food safety certification be financed? American Journal of Agricultural Economics, 83(4), 852-861.

Crespi, J. M. \& Marette, S. (2005). Eco-labelling economics: is public involvement necessary. Environment, information and consumer behavior, (pp. 93-110).

Crespi, J. M., Marette, S., et al. (2003). Some economic implications of public labeling. Journal of Food distribution research, 34(3), 83-94.

Darby, M. R. \& Karni, E. (1973). Free competition and the optimal amount of fraud. The Journal of Law and Economics, 16(1), 67-88. 
Disdier, A.-C. \& Marette, S. (2012). Taxes, minimum-quality standards and/or product labeling to improve environmental quality and welfare: Experiments can provide answers. Journal of Regulatory Economics, 41(3), 337-357.

Dosi, C. \& Moretto, M. (2001). Is ecolabelling a reliable environmental policy measure? Environmental and Resource Economics, 18(1), 113-127.

Dranove, D. \& Jin, G. Z. (2010). Quality disclosure and certification: Theory and practice. Journal of Economic Literature, 48(4), 935-63.

Ecolabel Index (2018). Website available at http: //www . ecolabelindex.com/. Accessed on August 2018.

Energy star (2018). Available at https: //www. energystar.gov/. Accessed on August 2018.

Fischer, C. \& Lyon, T. P. (2014). Competing environmental labels. Journal of Economics $\mathcal{E}$ Management Strategy, 23(3), 692-716.

Fischer, C. \& Lyon, T. P. (2016). A theory of multi-tier ecolabel competition. Technical report. Working Paper 1319.

Ford, G. T., Smith, D. B., \& Swasy, J. L. (1988). An empirical test of the search, experience and credence attributes framework. Advances in Consumer Research, 15, 239- 244.

Gadema, Z. \& Oglethorpe, D. (2011). The use and usefulness of carbon labelling food: A policy perspective from a survey of UK supermarket shoppers. Food Policy, 36(6), 815-822.

Galarraga Gallastegui, I. (2002). The use of eco-labels: A review of the literature. Environmental Policy and Governance, 12(6), 316-331.

Garbay, A. (July 25, 2018). En occitanie, un nouveau logo pour les viticulteurs «en conversion» vers le bio. Available at http://www.lefigaro.fr/conso/2018/07/25/ 20010-20180725ARTFIG00223-en-occitanie-un-nouveau-logo-pour-les-viticulteurs \ -en-conversion-vers-le-bio.php. Accessed on August 2018.

Golan, E., Kuchler, F., Mitchell, L., Greene, C., \& Jessup, A. (2001). Economics of food labeling. Journal of Consumer Policy, 24(2), 117-184.

Goulder, L. H. \& Parry, I. W. H. (2008). Instrument choice in environmental policy. Review of Environmental Economics and Policy, 2(2), 152-174.

Grolleau, G., Ibanez, L., \& Mzoughi, N. (2012). Being the best or doing the right thing? an investigation of positional, prosocial and conformist preferences in provision of public goods. The Journal of Socio-Economics, 41(5), 705-711.

Grolleau, G., Ibanez, L., Mzoughi, N., \& Teisl, M. (2016). Helping eco-labels to fulfil their promises. Climate Policy, 16(6), 792-802. 
Grunert, K. G. (2011). Sustainability in the Food Sector: A Consumer Behaviour Perspective. International Journal on Food System Dynamics, 2(3).

Grunert, K. G., Hieke, S., \& Wills, J. (2014). Sustainability labels on food products: Consumer motivation, understanding and use. Food Policy, 44(C), 177-189.

Gruère, G. P. (2014). An analysis of the growth in environmental labelling and information schemes. Journal of Consumer Policy, 38(1), 1-18.

Guéguen, L. \& Pascal, G. (2010). Le point sur la valeur nutritionnelle et sanitaire des aliments issus de l'agriculture biologique. Cahiers de Nutrition et de Diététique, 45(3), 130-143.

Hahn, R. \& Metcalfe, R. (2016). The impact of behavioral science experiments on energy policy. Economics of Energy E Environmental Policy, 5(2).

Hallstein, E. \& Villas-Boas, S. B. (2013). Can household consumers save the wild fish? lessons from a sustainable seafood advisory. Journal of Environmental Economics and Management, 66(1), $52-71$.

Hamilton, S. F. \& Zilberman, D. (2006). Green markets, eco-certification, and equilibrium fraud. Journal of Environmental Economics and Management, 52(3), 627-644.

Hassan, D. \& Monier-Dilhan, S. (2006). National brands and store brands: Competition through public quality labels. Agribusiness, 22(1), 21-30.

Heyes, A. G. \& Maxwell, J. W. (2004). Private vs. public regulation: political economy of the international environment. Journal of Environmental Economics and Management, 48(2), 978-996.

Horne, R. E. (2009). Limits to labels: The role of eco-labels in the assessment of product sustainability and routes to sustainable consumption. International Journal of Consumer Studies, 33(2), 175-182.

IATTC (2018). Inter-american tropical tuna commission. AIDCP Dolphin Safe. Website available at https://www . iattc.org/DolphinSafeENG.htm. Accessed on August 2018.

ISO (1999a). Environmental labels and declarations - type i environmental labelling - principles and procedures. ISO 14024. Geneve, Switzerland: ISO.

ISO (1999b). Environmental labels and declarations - type iii environmental labelling principles and procedures. ISO/DTR 14025. Geneve, Switzerland: ISO.

Jacquet, J., Pauly, D., Ainley, D., Holt, S., Dayton, P., \& Jackson, J. (2010). Seafood stewardship in crisis. Nature, 467, $28-29$.

Jaffry, S., Pickering, H., Ghulam, Y., Whitmarsh, D., \& Wattage, P. (2004). Consumer choices for quality and sustainability labelled seafood products in the uk. Food Policy, 29(3), 215-228. 
Joshi, M. (2004). Are eco-labels consistent with wto agreements? Journal of World Trade, 38(1), 69-92.

Kahneman, D. \& Knetsch, J. L. (1992). Valuing public goods: The purchase of moral satisfaction. Journal of Environmental Economics and Management, 22(1), 57 - 70.

Keller, K. L. \& Staelin, R. (1989). Assessing biases in measuring decision effectiveness and information overload. Journal of Consumer Research, 15(4), 504-508.

Kortelainen, M., Raychaudhuri, J., \& Roussillon, B. (2016). Effects Of Carbon Reduction Labels: Evidence From Scanner Data. Economic Inquiry, 54(2), 1167-1187.

Kotchen, M. J. (2005). Impure public goods and the comparative statics of environmentally friendly consumption. Journal of Environmental Economics and Management, 49(2), 281 - 300.

Lacroix, A., Muller, L., \& Ruffieux, B. (2017). Labelling for sustainable food : impact of nutritional and environmental logos in a food choice experiment. In Susdiet Newsletter, volume 6 (pp. $6-7$ ).

Li, Y. \& van 't Veld, K. (2015). Green, greener, greenest: Eco-label gradation and competition. Journal of Environmental Economics and Management, 72, 164 - 176.

List, J. A. \& Gallet, C. A. (2001). What experimental protocol influence disparities between actual and hypothetical stated values? Environmental and Resource Economics, 20(3), 241-254.

Lizzeri, A. (1999). Information revelation and certification intermediaries. The RAND Journal of Economics, 30(2), 214-231.

Loureiro, M. L., McCluskey, J. J., \& Mittelhammer, R. C. (2001). Assessing Consumer Preferences For Organic, Eco-Labeled, And Regular Apples. Journal of Agricultural and Resource Economics, 26(02).

Lusk, J. L., Nilsson, T., \& Foster, K. (2007). Public preferences and private choices: Effect of altruism and free riding on demand for environmentally certified pork. Environmental and Resource Economics, 36(4), 499-521.

Marchi, E. D., Caputo, V., Jr., R. M. N., \& Banterle, A. (2016). Time preferences and food choices: Evidence from a choice experiment. Food Policy, 62, 99 - 109.

Marette, S. (2010). Consumer confusion and multiple equilibria. Economics Bulletin, 30(2), 1120-1128.

Marette, S. (2014). Economics benefits coming from the absence of labels proliferation. Journal of Agricultural and Food Industrial Organization, 12(1), 1-9.

Marette, S. (2016). Label proliferation and consumers' confusion. the weak impact of sustainability labels on the value of chocolate. SUSDIET Newsletter, 4,5 . 
Marette, S., Messéan, A., \& Millet, G. (2012). Consumers' willingness to pay for eco-friendly apples under different labels: Evidences from a lab experiment. Food Policy, 37(2), 151 161.

Marette, S., Roosen, J., \& Blanchemanche, S. (2008). Taxes and subsidies to change eating habits when information is not enough: an application to fish consumption. Journal of Regulatory Economics, 34(2), 119-143.

Mason, C. F. \& Sterbenz, F. P. (1994). Imperfect product testing and market size. International Economic Review, 35(1), 61-86.

Messer, K. D., Costanigro, M., \& Kaiser, H. M. (2017). Labeling food processes: The good, the bad and the ugly. Applied Economic Perspectives and Policy, 39(3), 407-427.

Michaud, C., Llerena, D., \& Joly, I. (2013). Willingness to pay for environmental attributes of non-food agricultural products: a real choice experiment. European Review of Agricultural Economics, 40(2), 313.

Min, J., Azevedo, I. L., Michalek, J., \& de Bruin, W. B. (2014). Labeling energy cost on light bulbs lowers implicit discount rates. Ecological Economics, 97(Supplement C), 42 - 50.

Mondelaers, K., Verbeke, W., \& Huylenbroeck, G. V. (2009). Importance of health and environment as quality traits in the buying decision of organic products. British Food Journal, 111(10), 1120-1139.

Mussa, M. \& Rosen, S. (1978). Monopoly and product quality. Journal of Economic Theory, $18(2), 301-317$.

Nimon, W. \& Beghin, J. (1999a). Are eco-labels valuable? evidence from the apparel industry. American Journal of Agricultural Economics, 81(4), 801-811.

Nimon, W. \& Beghin, J. (1999b). Ecolabels and international trade in the textile and apparel market. American Journal of Agricultural Economics, 81(5), 1078-1083.

Olesen, I., Alfnes, F., Røra, M. B., \& Kolstad, K. (2010). Eliciting consumers' willingness to pay for organic and welfare-labelled salmon in a non-hypothetical choice experiment. Livestock Science, 127(2), $218-226$.

Prieto-Sandoval, V., Alfaro, J. A., Mejía-Villa, A., \& Ormazabal, M. (2016). Eco-labels as a multidimensional research topic: Trends and opportunities. Journal of Cleaner Production, $135,806-818$.

Roe, B. \& Sheldon, I. (2007). Credence good labeling: The efficiency and distributional implications of several policy approaches. American Journal of Agricultural Economics, 89(4), 1020-1033. 
Roe, B. E., Teisl, M. F., \& Deans, C. R. (2014). The economics of voluntary versus mandatory labels. Annual Review of Resource Economics, 6(1), 407-427.

Roheim, C. A., Asche, F., \& Santos, J. I. (2011). The elusive price premium for ecolabelled products: Evidence from seafood in the uk market. Journal of Agricultural Economics, 62(3), 655-668.

Rousseau, S. (2015). The role of organic and fair trade labels when choosing chocolate. Food Quality and Preference, 44, 92-100.

Scarpa, R., Thiene, M., \& Marangon, F. (2008). Using Flexible Taste Distributions to Value Collective Reputation for Environmentally Friendly Production Methods. Canadian Journal of Agricultural Economics/Revue canadienne d'agroeconomie, 56(2), 145-162.

Schmit, T. M., Rickard, B. J., \& Taber, J. (2013). Consumer valuation of environmentally friendly production practices in wines, considering asymmetric information and sensory effects. Journal of Agricultural Economics, 64(2), 483-504.

Schubert, C. (2017). Green nudges: Do they work? are they ethical? Ecological Economics, 132(Supplement C), $329-342$.

Sheldon, I. M., Roe, B. E., et al. (2009). Public vs. private eco-labeling of environmental credence goods: Maximizing the gains from international integration. Journal of Agricultural $\mathcal{E}$ Food Industrial Organization, 7(2), 1-29.

Sörqvist, P., Hedblom, D., Holmgren, M., Haga, A., Langeborg, L., Nöstl, A., \& Kågström, J. (2013). Who needs cream and sugar when there is eco-labeling? taste and willingness to pay for "eco-friendly" coffee. PLOS ONE, 8(12), 1-9.

Teisl, M. (2017). Labelling Strategies in Environmental Policy. Ashgate Publishing Limited.

Teisl, M. F. (2003). What we may have is a failure to communicate: Labeling environmentally certified forest products. Forest Science, 49, 668-680.

Teisl, M. F., Peavey, S., Newman, F., Buono, J., \& Hermann, M. (2002a). Consumer reactions to environmental labels for forest products: A preliminary look. Forest Products Journal, $52(1), 44$.

Teisl, M. F. \& Roe, B. (1998). The economics of labeling: An overview of issues for health and environmental disclosure. Agricultural and Resource Economics Review, 27(2), 140-150.

Teisl, M. F., Roe, B., \& Hicks, R. L. (2002b). Can eco-labels tune a market? evidence from dolphin-safe labeling. Journal of Environmental Economics and Management, 43(3), 339 - 359.

Teisl, M. F., Roe, B., \& Levy, A. S. (1999). Ecocertification: Why it may not be a "field of dreams.". American Journal of Agricultural Economics, 81, 1066. 
Thøgersen, J. (2000). Psychological determinants of paying attention to eco-labels in purchase decisions: Model development and multinational validation. Journal of Consumer Policy, 23, $285-313$.

Tian, H. (2004). Eco-labelling scheme, environmental protection, and protectionism. Canadian Journal of Economics/Revue canadienne d'économique, 36(3), 608-633.

Tiebout, C. M. (1956). A pure theory of local expenditures. Journal of political economy, 64(5), 416-424.

Tranter, R., Bennett, R., Costa, L., Cowan, C., Holt, G., Jones, P., Miele, M., Sottomayor, M., \& Vestergaard, J. (2009). Consumers' willingness-to-pay for organic conversion-grade food: Evidence from five eu countries. Food Policy, 34(3), 287 - 294.

van Herpen, E., Fischer, A. R., \& van Trijp, H. C. (2015). How to position 'mildly sustainable' products: The joint impact of assortment display and price setting. Food Quality and Preference, 46, $26-32$.

Van Loo, E. J., Caputo, V., Nayga, R. M., Seo, H.-S., Zhang, B., \& Verbeke, W. (2015). Sustainability labels on coffee: Consumer preferences, willingness-to-pay and visual attention to attributes. Ecological Economics, 118(C), 215-225.

Van Loo, E. J., Caputo, V., Nayga, R. M., \& Verbeke, W. (2014). Consumers' valuation of sustainability labels on meat. Food Policy, 49(P1), 137-150.

Van't Veld, K. \& Kotchen, M. J. (2011). Green clubs. Journal of Environmental Economics and Management, 62(3), 309-322.

Vlaeminck, P., Jiang, T., \& Vranken, L. (2014). Food labeling and eco-friendly consumption: Experimental evidence from a belgian supermarket. Ecological Economics, 108(Supplement C), $180-190$.

Walter, J. \& Chang, Y.-M. (2017). Green certification, heterogeneous producers, and green consumers: a welfare analysis of environmental regulations. Journal of Regulatory Economics, 52(3), 333-361.

Wansink, B., Sonka, S. T., \& Hasler, C. M. (2004). Front-label health claims: when less is more. Food Policy, 29(6), 659-667.

Xu, P., Zeng, Y., Fong, Q., Lone, T., \& Liu, Y. (2012). Chinese consumers' willingness to pay for green- and eco-labeled seafood. Food Control, 28(1), $74-82$. 


\section{Appendix}

We use a simple, stylized framework. Many extensions are possible. The assumptions are the following.

\section{The assumptions}

For simplicity, trade occurs in a single period. We consider either a monopoly situation or a duopoly situation, namely 1 or 2 firms producing products. We do not detail the firms' entry related to other fixed costs that are not studied.

Firm(s) can choose to produce high or low-quality products. We assume that the marginal cost of producing high-quality products is $h>0$ and relatively low, while the marginal cost of producing low-quality products is zero. The specific quality of each commodity is known by each firm but is not observed by consumers or other firms.

Consumers are risk neutral and want to purchase only one unit of the good. The parameter $k>0$ represents the quality level of a product. A consumer has a WTP equal to $\theta k$ but differs in his or her willingness to pay for the quality, which is described by the uniformly distributed parameter $\theta \in[0,1]$. For the sake of simplicity and without loss of generality, the mass of consumers is normalized at unity. A consumer who buys one unit of a quality $k$ at a price of $p$ has an indirect utility equal to $\theta k-p$ (see Mussa \& Rosen, 1978). The high-quality is denoted $k_{h}$ and the low-quality is denoted $k_{l}$, with $k_{h}>k_{l}>0$.

We assume that only one certification agency is able to provide a perfect and credible certification regarding the high-quality signaled by the label. This certification agency charges a fixed fee/cost $C$ to firm(s) for guaranteeing the certification credibility related to the label. This fixed fee/cost is sunk for a firm incurring it. This certification is the only credible way to signal quality to consumers or other firms.

The single round of trading proceeds in 3 stages. In stage 1, the regulator selects its policy, namely whether or not to propose mandatory certification (study with figures 2 and 3). For the sake of simplicity, there is no opportunity cost of public funds and no cost of regulation. In stage 2 , producers simultaneously choose whether or not to produce high-quality products and whether or not to certify these products (e.g., "high-quality with certification"), with every firm and every consumer observing the certification results. In stage 3, firm(s) simultaneously set prices (with a price competition under duopoly). Price choices and decisions to certify are defined by backward induction under a subgame perfect equilibrium. 


\section{The absence of certification}

As a basis for the analysis that follows, first consider the scenario where quality certification does not exist. In this case, because of their lower cost, only low-quality products will be offered. Consumers fully expect this outcome, as there is no credible certification available at this point (see Akerlof, 1970).

When a certification is available, we next consider the two configurations, namely the monopoly and the duopoly.

\section{Certification under monopoly}

Before studying the firm's incentive to choose high-quality and certification (stage 2), we study the price decision (stage 3 ). For a quality $k$ and a price $p$ chosen by the monopolist, consumer would knowingly purchase a quality $k$. The consumer indifferent between buying a product and buying nothing is identified by the preference parameter $\tilde{\theta}=p / k$ (such that $\theta k-p)$, which leads to a demand for a product of $\int_{\tilde{\theta}}^{1} \mathrm{~d} \theta=1-p / k$, since the parameter $\theta$ is uniformly distributed between 0 and 1 . The price at stage 3 is determined for a given level of quality previously selected.

When the monopolist selects high-quality products, it incurs the certification cost $C$ and the marginal cost $h$, consumers know that high-quality is offered. With a demand for certified products equal to $1-p / k_{h}$, the monopolist chooses $p$ to maximize its profit $(p-h)\left(1-p / k_{h}\right)-C$, resulting in an equilibrium price $p_{m}=\left(k_{h}+h\right) / 2$. This price leads to an equilibrium profit equal to $\pi_{m h}=\left(k_{h}-h\right)^{2} / 4 k h-C$. The consumers' surplus is then $C S_{m h}=\int_{\frac{p_{m}}{k_{h}}}^{1}\left(\theta k_{h}-p_{m}\right) \mathrm{d} \theta=\left(k_{h}-h\right)^{2} / 8 k$. The overall welfare is $W_{m h}=C S_{m h}+\pi_{m h}$.

When the monopolist selects the low-quality products, the profit at the optimum is $\pi_{m l}=k_{l} / 4$ and the surplus is $C S_{m l}=k_{l} / 8$. The overall welfare is $W_{m l}=C S_{m l}+\pi_{m l}$.

At stage 2, the monopolist voluntary selects high-quality products and certify its products with the label, as soon as its profit $\pi_{m h}$ is greater than $\pi_{m l}$, which corresponds to the constraint $C<C_{1}$, represented on figures 1 and 3 . It was assumed that $h$ was relatively low always guaranteeing $\pi_{m h}>\pi_{m l}$ and $C_{1}>0$. The other frontier represented on figure 1 will be detailed below with the duopoly case.

Figure 3 details the regulator's choice maximizing the welfare under monopoly. At stage 1 , the regulator chooses to impose the mandatory label and the certification, when the monopolist does not choose the label for $C>C_{1}$ and when the welfare $W_{m h}$ is greater than $W_{m l}$, which corresponds to the constraint $C<C_{3}$, represented on figure 3 . When labels are mandatory, the inequality $\pi_{m h}-C>\pi_{m l}-C$ is always satisfied, guarantying the choice of high quality. For $C<C_{3}$, the inequality $\pi_{m h}>0$ is very often satisfied. When $C>C_{3}$, nothing is imposed since $W_{m l}>W_{m h}$. 


\section{Certification under duopoly}

Under price competition at stage 3, the selection of the same quality by both firms leads to the same price equal to the marginal cost. The homogeneity of quality reduces prices to marginal cost. When both firms offer the same quality, gross profits not accounting for fixed/sunk fees are zero.

If both firms select low-quality products, the price is equal to zero, the profits are zero and the consumers' surplus also equal to the welfare is $C S_{d l}=\int_{0}^{1} \theta k_{l} \mathrm{~d} \theta=k_{l} / 2$, with $\theta$ uniformly distributed between 0 and 1 .

Because of the fixed fee $C$ related to the certification, both firms cannot simultaneously select the high-quality products leading to a gross profit equal to zero and to a loss equal to $C$ for each firm, when this certification cost is incurred by each firm. With a price equal to the marginal cost $h$, the consumers' surplus would be equal to $C S_{d h}=\int_{h / k_{h}}^{1}\left(\theta k_{h}-h\right) \mathrm{d} \theta=$ $\frac{\left(k_{h}-h\right)^{2}}{2 k_{h}}$ and the welfare would be equal to $W_{d h}=C S_{d h}-2 C$.

Under price competition, only one firm can produce high-quality products and pay the cost of certification $C$ due to a positive profit on the segment of high-quality products. In this case, the consumer indifferent between high-quality products and low-quality product is defined by $\bar{\theta}=\left(p_{h}-p_{l}\right) /\left(k_{h}-k_{l}\right)$. The parameter $\tilde{\theta}=p_{l} / k_{l}$, defines the consumer indifference between consuming low-quality and not purchasing. Since the parameter $\theta k$ is uniformly distributed, the demand for high-quality product is $1-\left[\left(p_{h}-p_{l}\right) /\left(k_{h}-k_{l}\right)\right]$ and the demand for low-quality products is $\left.\left(p_{h}-p_{l}\right) /\left(k_{h}-k_{l}\right)-p_{l}\right) /\left(k_{l}\right.$. Both firms maximize the following profits, namely $\pi_{d h}=\left(p_{h}-h\right) 1-\left[\left(p_{h}-p_{l}\right) /\left(k_{h}-k_{l}\right)\right]-C$ for the firm with high-quality products and the certification cost and $\pi_{d l}=p_{l}\left(\left(p_{h}-p_{l}\right) /\left(k_{h}-k_{l}\right)-p_{l} / k_{l}\right)$ for the firm with low-quality products. The profits maximization leads to equilibrium prices, $p_{h} *$ and $p_{l} *$. At the equilibrium, the profits are

$$
\begin{aligned}
& \pi_{d h}=\left[2 k_{h}\left(k_{h}-k_{l}\right)-h\left(2 k_{h}-k_{l}\right)\right]^{2} /\left(k_{h}-k_{l}\right)\left(4 k_{h}-k_{l}\right)^{2}-C \\
& \pi_{d l}=k_{h} k_{l}\left(k_{h}-k_{l}+h\right)^{2} /\left(k_{h}-k_{l}\right)\left(4 k_{h}-k_{l}\right)^{2}
\end{aligned}
$$

The consumers' surplus is

$$
\begin{gathered}
C S_{d h l}=\int_{\frac{p_{l} *}{k_{h}}}^{\frac{p_{h^{*}-p_{l}}}{k_{h}-k_{l}}}\left(\theta k_{l}-p_{l} *\right) \mathrm{d} \theta+\int_{\frac{p_{h^{*}-p_{l}}}{k_{h}-k_{l}}}^{1}\left(\theta k_{h}-p_{h^{*}} *\right) \mathrm{d} \theta=k_{h}\left[k_{l}^{2}\left(2 h-5 k_{h}\right)+4 k_{h}\left(k_{h}-h\right)^{2}+\right. \\
\left.k_{l}\left(k_{h}^{2}+6 h k_{h}-3 h^{2}\right)\right] / 2\left(k_{h}-k_{l}\right)\left(4 k_{h}-k_{l}\right)^{2}
\end{gathered}
$$

and the welfare is $W_{d h l}=\pi_{d h}+\pi_{d l}+C S_{d h l}$

At stage 2, one firm voluntary selects the label and certify its products, as soon as its profit $\pi_{d h}$ is greater than 0 , corresponding to the profit when both firms choose the low-quality products. The constraint $\pi_{d h}>0$ corresponds to the constraint $C<C_{2}$, represented on figures 1 and 4 . The frontier $C_{2}$ complements figures 1 detailing the private incentives of firms. 
Figure 4 details the regulator's choice maximizing the welfare under dupoly. At stage 1, the regulator likes to have both firms choosing the label and high-quality when $W_{d h}$ is greater than $W_{d h l}$, which corresponds to $C<C_{4}$, represented on figure 4 . When $C<C_{4}$, it is optimal to fully subsidize the certification cost $C$ to each firm, and to select a high-quality standard banning low quality, for having both firms selecting high-quality products leading to a price equal to $h$. Without this high-quality standard, 1 firm would select the high-quality and the other one, the low-quality, for differentiating their products and maximizing their profits. Recall that there is no opportunity cost of public funds.

For relatively high values of the certification cost, the regulator likes to have one firm choosing the label when $W_{d h l}$ is greater than $C S_{d l}$ that is the welfare when both firms choose low-quality products. $W_{d h l}>C S_{d l}$ corresponding to $C<C_{5}$ is represented on figure 4 . When one firm does not choose the label for $C>C_{2}$ and when $C<C_{5}$, the regulator subsidizes the certification with a subsidy $S$ such that $\pi_{d h}+S>0$ and $S$ being the lowest possible level. 